Journal of Social Sciences 5(4): 314-318, 2009

ISSN 1549-3652

(C) 2009 Science Publications

\title{
Developing Ornamental Plants for Promoting Community Economy
}

\author{
${ }^{1}$ Kritsana Khonphian, ${ }^{2}$ Wirat Pansila and ${ }^{3}$ Prasopsuk Ritthidet \\ ${ }^{1}$ Department of Thai Studies, Faculty of Art and Culture, \\ The Research Institute of Northeastern, Mahasarakham University, Thailand, 44150 \\ ${ }^{2}$ Department of Public Health, Public Health Faculty, \\ Mahasarakham University, Thailand, 44150 \\ ${ }^{3}$ Department of Curriculum and Instruction, Education Faculty, \\ Rajabhat Mahasarakham University, Thailand, 44000
}

\begin{abstract}
Problem statement: This study aimed to investigate the development of ornamental plants for promoting community economy in marketing and product selling. The study area was Ban Mai Udom, Tambon Ban Mai, Amphoe Nong Bunmak, Changwat Nakhon Ratchasima. Approach: This qualitative research study collected documentary data and field data using survey, observations, interviews and focused group discussion. The sample consisted of totally 33 community leaders, ornamental plant producers sellers and buyers and state and private sector officials involving promotion of ornamental plant production and selling, obtained using the simple random sampling technique. The collected data were checked using the triangulation technique. The data were analyzed and the study findings were presented by means of a descriptive analysis. Results: The study findings revealed that the production of ornamental plants in Ban Mai Udom community had 2 types of development for promoting community economy: At the household level and the organizational level. At the household kevel, the problems of marketing and selling, in which prices could be bargained, by selling by themselves and haring their relatives sell the products a local markets both inside and outside the community. At the organization level, the patterns of promoting community economy were developed. The marketing problems were solved by using the concept of media through indigenous knowledge, setting up groups as an organization through ethnicity of Thai Khorat and using the Thai Khorat dialect. Conclusion: In solving the selling problems, all of the group members sold the products at local markets and foreign markets such as France, Hong Kong and Dubai. When they had got money, every group member could borrow some money as welfare at an interest rate of $2 \%$ year. Dividends were given to all group members every year. The methods mentioned could solve different problems involved.
\end{abstract}

Key words: Ornamental plants, ornamental plant development, promoting community economy, northeast Thailand communities

\section{INTRODUCTION}

Naturally living things must adapt themselves. When the society changes to production and selling in the market system, it will change to competitions and building capitalist economic status with an emphasis on the importance of materialism. For survival and better life, it is necessary to rely more on outside society, affecting the way of life on the bases of substantial production and destruction of assistance of community people. Marketing concerning ornamental plant production at Ban Mai community, Amphoe Nong Bunmak, Changwat Nakhon Ratchasima unity, clearly indicates developments of Ban Mai Udom community.
In the past, existence of this community was the self-reliant economy system. There appeared love, unity, assistance, trust, exchanges and help with one another. Group forming was power of community people by using indigenous knowledge of producing ornamental plants. There were no adjustments of ornamental plants to have new and strange shapes. Later, when there was development by the state sector, capitalism extended into the community. The state policy focused mainly on development of economic growth $^{[1]}$. It changed to production for upgrading the economic status by emphasizing increment of incomes. Buying and selling in the marketing system at the

Corresponding Author: Kritsana Khonphian, Faculty of Art and Culture, The Research Institute of Northeastern, Mahasarakham University, Thailand, 44150 Tel: +66-43-741686 Fax: +66-43-741686 
household and community levels generated effects on such various economic factors as buying power, incomes, saving and expenses. These economic factors had close relationships with development of the ornamental plant of Bougainvillea.

In particular in market share, it was found that there were these 2 patterns: The development pattern at the household level relied on selling at local markets within and outside the village in the type of selling products by themselves and for the development pattern at the organization level, the members for med groups to buy and sell products at the local markets and domestic and foreign markets with these two dual characteristics: Self-reliance and reliance relatives of Thai Khorat ethnic group.

\section{MATERIALS AND METHODS}

In competition on selling ornamental plants in the capitalist marketing system, the method used was oral historical examination of community histories and production of ornamental plants by using a survey form, structured- and unstructured-interview forms, participant and non participants observation forms and focused group discussion with 33 informants.

\section{RESULTS}

\section{History:}

Ban Mai Udom community: Ban Mai Udom community history;Ban Mai Udom is a village whose villagers moved from Amphoe Non Thai, Changwat Nakhon Ratchasima. It is thai Khorat ethnic group with two other mixed ethnic groups comprising Thai-Lab ethnic group and Thai-Khmer ethnic group. Ban Mai Udom villagers in the early period came to reserve and clear the land for living-making. They had the way of life tied to nature and made their livings chiefly by rice farming. Their supplementary occupations were up land-crop farming and gardening. Their foods could be sought from natural water sources and forests in the community area. They used the simple way of life with self-reliant economy like Isan people in general ${ }^{[2]}$. The community built relationships through living-making activities in some important matters such as labor sharing, trade sharing and food sharing. The social condition was a kinship type. The community had various traditions, culture, beliefs and rituals to uphold and practice together. The villagers performed Brahmin, Buddhist and animist rituals in a strict way. One ritual to which the community gave the special importance was Bun Bock Ban (village merit-making ceremony) held on the 14th and 15th days of the waxing moon in the sixth lunar month every year. Ban Mai Udon community participates in the ceremony with Ban Thanon Hub community because they have successively upheld and practiced the ceremony for a long time. A village hall is on the square approximately $2 \mathrm{~km}$ northward Ban Mai udom community. In the ceremony performance tradition, they invite Buddhist monks to receive food and alms and to say prayers for auspiciousness. After that, there is play of throwing water. Then the villagers go to the Holy House of $\mathrm{Pu} \mathrm{Ta}$ (the village guardian spirit) to offer food and ask for good luck. Their agricultural products from or namental plant of Bougainvillaca can male good profits. For producing ornamental plant of Bougainvillaca, village sages transfer their knowledge to relatives and there are more interested people in general. They invent new models of dwarfed trees of ornamental plant to have more interacting shapes which can meet the market needs and extend more networks. These factors enable Ban Mai Udom community to exist as a strengthened community in self-reliant economy form planting ornamental plant of Bougainvillaca.

Changes in the marketing systems and living of Ban Mai Udom community people: For the community phenomena from the past, particularly during the linking time of the policy for adjusting the country to modernization with the First National Social and Economic Development Plan, beginning in 1961, it was found that the community was impacted by the government's policy. This caused the community people to change the way to commercial production and from limited consumption within the produced products of what could be obtained in the community to buying goods for factors of production and consumption. Extension of the capitalist system into the community did not increase products to the community. Conversely, trade marketing of the community people took away the profits from the community through the unfair trade system because the government focused mainly on development for economic growths. The community culture has been rolling. placed by a new series of culture coming with globalization production, consumption and socio culture following capitalism ${ }^{[3]}$. It is the culture which must rely on capital funds and modern knowledge technology. The changer in values and beliefs can cause the community people to be more selfish. Reliance on other people by asking for labor must change to labor hiring. Food sharing must change to food selling. There are only activities concerning community traditions and rituals left to which all community people give the import-ance such as unity, assistance and trust in one another. Group forming is 
community power and it is the way of life in existence in Ban Mai Udom community up to the present.

Marketing management of ornamental plants in Ban Mai Udon community: Ban Mai Udom community people mainly earn their livings by rice farming as a chief career and upland-cop farming and trading as supplementary careers. When forests and nature were destroyed, the soil richness decreased and droughts occurred continuously. Biological diversity was destroyed rapidly. Living of the community people in the self-reliant economic system was replaced by the stream of modern economic system in rapidity. As a result, agricultural products did not have fixed prices. The community people accumulated materials exceeding their own potentials. Their debts increased. Some families had to have their children leave schools to make living in other careers to bring a part of incomes to support their families. With awareness of the problems arisen, the community people realized the importance of indigenous knowledge. The pattern of developing ornamental plants from Bougainnaea originated from a community sage named Mr. Prakop Butsaket who had the body of knowledge of Bougainnaea ornamental plant production. The community people met and discussed for reviatalization and conservation of indigenous knowledge which began in 1994. In the early period they produced and sold the plants by themselves. Those interested could buy them. This was the original concept. In the second period, they grew the ornamental plants for sale. They adjusted the plants of Bougainnaea to be in many different shapes and sold them. It was an applied concept. In the third period they sold the products through middlemen in the type of breeding Bougainnaea to have diversity with different pretty colors. The plants were grown in enameled pots with different pretty patterns from Changwat Ratchaburi. They used the technology of selling through Internet as media of public relations. This is a new concept. Marketing is a tool in the economic system leading to building incomes through the following cultural networks: Relatives operated trading within the community market. When there was the market, their children took the products to sell or they opened more market branches outside the community. For operation, their children living at other places took the products to sell or they told other groups of the Thai Khorat ethnic group. They sold the products within the community. When they know that these types of Bougainnaea belonged to Khorat people, they would buy the products from Khorat people like them. Outside the community, their children who lived at other places took the products to sell or told about the products to people in the Thai Khorat ethnic group. They also invited other people to buy the products. The method mentioned is transference of the body of knowledge of Bougainnaea through the system of relatives who worship the same ancestors' spirits ${ }^{[4]}$. The marketing system outside the community had operation by developing strange and new models to attract interests of those who saw Baugainnaea. There were Bougainnaea with many different colors. For selling operation, when any group member did not have enough plants or sell, he or she could receive them from other group members. The plants could be returned later or paid in cash at the production cost. Outside the community, shops or familiar people trusted one another in the Bougainnaes business Circle. Sometimes they bought products on credit and paid for tem later.

Integration of prior knowledge into new knowledge
of developing Bougainnaea ornamental plants for
promoting Ban Udon community economy: Development of ornamental plants at Ban Mai Udom in the past feed marketing problems. Marketing problems are very important to living in the daily life. Everyone had involvement in goods exchanged in the marketing system. General experiences in marketing such as exchanges of toys with friends are not complicated. However, in reality marketing is complicated with a very wide scope. There are inventions and integration by using raw materials, objects and modern agricultural technology for producing Bougainnaea ornamental plants. They integrated prior knowledge into new knowledge in making various shapes of ornamental plants. They adj Usted Bougainnaea to be such different shapes of the plants as bush, mushroom, dragon, pyramid and different animals (elephant, bird, drgonbly, butter-fly, dinosaur, deer and giraffe) and other different independent shapes as ordered by customers. They adapted the shapes cursing wires to tie the plants into different shapes. When the small branches had young leaves and long sticks, they would insert the sticks along the shape as needed. It is an applied concept and the marketing system of Bougainnaea production for sale through middlemen. They bred the plants to Rave Various colors to the market needs. Also, they integrated the applied concept into other concepts supplement to selection of pots with various shapes and colors and with durability. Emphases were on concepts of beliefs and auspicious names as will as materials such as dragon-patterned pots from ratchaburi. The plants were arranged in groups with outstanding order of Bougainnaca plants. They used modern technology media to buy and sell through Internet. Public relations and selling ornamental plants 
were marketing management within the community. Interested people could buy the plants to decorate their places for beauty.

The marketing network for developing ornamental plants from social capital within and outside the community: For the development of Bougainnaea ornamental pant production within the community which originated from behaviors of network members, these members helped one another, relied on each other and realized the value of indigenous knowledge as social capital of community people for developing ornamental plant production together. It was found that the development originated from forming groups for Bougainnaea plant production within Ban Mai Udon community. A Community sage named Mr. Prakop Butsaket and the group of Bougainnaea plant producers led by Mrs. Somphon Wangprasopklang as the network of learning sharing through training knowledge and field trips together with community members and young people. In addition, there was social capital from many different agencies which were outside organizations such as Tambol Ban Mai Administrative Organization, Office of Amphoe Nong Bunmak Development, Office of Chaugwat Nakhon ratchasima Development, Amphoe Nong Bunmak Agriculture and Changwat Nakhon Ratchasima Agriculture. These agencies had their roles in participation in operating of training to provide knowledge to business entrepreneurs and interested people to have knowledge and understanding of ornamental plant production and the direction of present and future marketing. Building networked markets which generated from the group of ornamental plant production was the environmental factor that helped support to have development of patterns of ornamental plants in Ban Mai Udom community to exist. Also, it was community economic promotion to generate at the household level and at the Bougainnaea plant production group level. It was the building of social relationships from inside and outside community people to cooperatively conserve and adhere to indigenous knowledge of Bougainnaea plant production to exist in the community and to extend it to other community networks. Moreover, it was found that community economy emerged from Bougainnaea plant production to generate incomes. From a case study of agricultural production of Bougainnaea plants, it was found that they earned an income of about 15,000 baht per month in regularity and the production group had financial welfare for the members to borrow for suffering problem-solving in the doily life ${ }^{[5]}$.

\section{DISCUSSION}

Developing ornamental plants for promoting community economy in northeast Thailand as a case study of ban Mai Udom Community, Thambol Ban Mai, Amphoe Nong Bunmak, Changwat Nakhon Ratchasima had these 2 patterns of development for community economy promotion: At the household level, ornamental plants were sold by the household members themselves at local market in the community which could be bargained and the products were sold outside the community by the product owners' relatives. For the ornamental plant development at the group level, the marketing problems were solved by using the concept of media through indigenous knowledge by means of by means of forming groups and organizations through Thai Khorat ethnicity and using Khorat dialect for communication among them. Community economic promotion used these 2 types. At the household level they relied on themselves by directly selling ornamental plants not through middlemen. Families could rely on themselves. At the group level they relied on labor from every group member for selling products. When some members were in trouble, they could borrow some money as welfare at a low interest rate. It was found that the pattern of developing Bougainnaea plants at the household level used local people in the villages and outside the villages to buy and sell, products by themselves. For the pattern of developing Bougainnaea plants at the group level, group members cooperatively sold the products at local markets in the country and foreign countries. Existence of Bougainnaea in the community was self-reliance and relying on group of relatives in the Thai Khorat ethnic group. There was welfare in the organization. They had attachment to each other and sent goods to their relatives, causing ornamental plant development for community economy to become the pattern of culture of relatives in the same ethnic group.

\section{CONCLUSION}

For production of ornamental Baugainnaea plants, what we should think of are the marketing system, production capital, values and breeds of Bougainnaea plants. This can be done by establishing the learning center to display the background, production, production technique, maintenance, beliefs, different patterns and techniques of selecting to buy Bougainnaea plants. There should be positive awareness. Producers and business entrepreneurs must be honest to their customers. They should promote 
learning involving production and selling Bougainnaea ornamental plants both in formal education and nonformal education in earnestly and continuity for building community economic values. Development of a variety of patterns of Bougainnaea ornamental plants should be promoted by all agencies involved in continuity. This could be done by holding training and seminars to provide knowledge, field trips, marketing, public relations and organization of supporting activities such as organization of flower and ornamental plants fair, conservation tourism-along the road of civilization of Ban Mai Udom. These things could cause economy to rotate within the community. They would be power to drive economy in the type of selfreliant community economy with culture of belief in the same ancestors' spirits and speaking the same Khorat dialect.

\section{ACKNOWLEDGEMENT}

The researchers express their sincere appreciation for all of support provided and the referees for their helpful comments.

\section{REFERENCES}

1. Rithidet, P., P. Piampongsan, P. Prathepa and B. Yodmalee, 2005. The development of community economic system of Thung Kula Ronghai Famers at Ban Ta Yuak, Northeastern Thailand. J. Soc. Sci., 1: 240-242.

http://www.scipub.org/fulltext/jss/jss14240-

242.pdf
2. Nartsupha, C., 2003. The Thai village economy in the past. J. Econ. History, 63: 265-266. http://ideas.repec.org/a/cup/jechis/v63y2003i01p26 5-266_33.html

3. Sati, P., J. Dhamawat, P. Pratepha and S. Rittidech, 2005. Changes in the conscious mind in applying technology for growing rice at the Chee River Basin in Northeastern of Thailand. J. Soc. Sci., 1: 172-177. http://www.scipub.org/fulltext/jss/jss13172-177.pdf

4. Pothisan, W., A. Nantajak, P. Rittidet and B. Saenyabud, 2008. The social adjustment of the Kuy people to a multicultural context in Southern Isan Thailand. J. Soc. Sci., 4: 343-346.

http://www.scipub.org/fulltext/jss/jss44343-346.pdf

5. Sata, W., V. Vinai, P. Bowjai and Rithidet, 2008. Environmental change of Lompao dam communities in Northeast Thailand. J. Soc. Sci., 4: 334-337.

http://www.scipub.org/fulltext/jss/jss44334-337.pdf 